\title{
PAINTING MATERIALS INVESTIGATION FROM DRAGU WOODEN CHURCH, SALAJ COUNTY
}

\author{
VICTOR CONSTANTIN MARUTOIUa, IOAN BRATU ${ }^{b^{*}}$, \\ OLIVIA FLORENA NEMES ${ }^{a}$, CONSTANTIN MARUTOIU ${ }^{a}$
}

\begin{abstract}
The old wooden church from Dragu, Sălaj County, was built on the hill of Dragu village between 1806 and 1809, according to the inscription found inside. The investigations targeted the imperial gates (the main entry from the nave to the altar used by the priest during church service and adorned with painted icons and elaborated wood sculpture) and aimed to identify the materials used for their manufacture: the wood species, pigments, ground, binders. For the identification of materials two spectroscopic methods were employed: XRF (X-ray fluorescence) and FTIR (Fourier transform IR absorption). The employed materials are: linden wood for the imperial gates, gypsum for ground; lead white, Prussian blue, gold and silver leaf, iron red, lead red, cinnabar, realgar, orpiment, Scheele's green for pigments; egg yolk and bone glue as binders.
\end{abstract}

Keywords: XRF - non-destructive spectroscopy, FTIR absorption destructive spectroscopy, wooden church, imperial gates, painting materials, pigments

\section{INTRODUCTION}

The church, Fig 1, was built between 1806 and 1809, information available from the inscription found next to the church entry and is dedicated to St. Basil the Great. The structure has a rectangular shape with an attached altar apse, specific to the Transylvanian architecture and a covered porch on two sides. The high raising bell tower gives monumentality to the structure. The base of the tower is open with four arches on each side. It's four corners are decorated with small towers. On the interior, the narthex is covered with a level ceiling, the nave with a semi-cylindrical vault and the altar with an

a Babeş-Bolyai University, Faculty of Orthodox Theology, F/N Episcop Nicolae Ivan St., 400117 Cluj-Napoca, Romania

b National Institute for R\&D on Isotopic and Molecular Technologies, 67-103 Donath St., 400293, Cluj-Napoca, Romania

* Corresponding author: ibratu@gmail.com 
VICTOR CONSTANTIN MARUTOIU, IOAN BRATU,

OLIVIA FLORENA NEMES, CONSTANTIN MARUTOIU

arching. The original painting can still be seen on the narthex walls (the nave painting was degraded by water ingress). The altarpiece was sculpted and painted in 1815 [1-6].
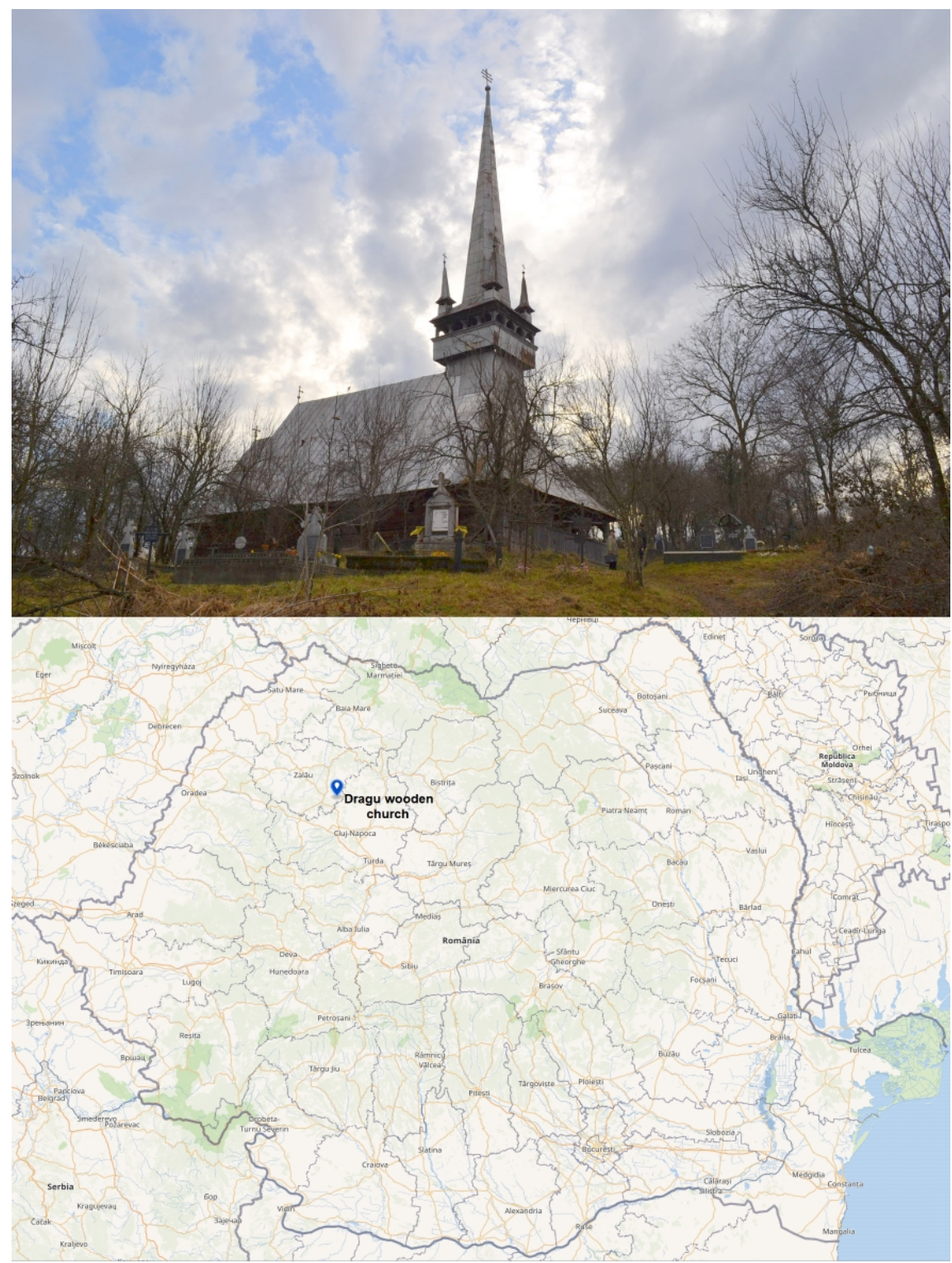

Figure 1. Old wooden church from Dragu village, Sălaj County and its location on the map. 


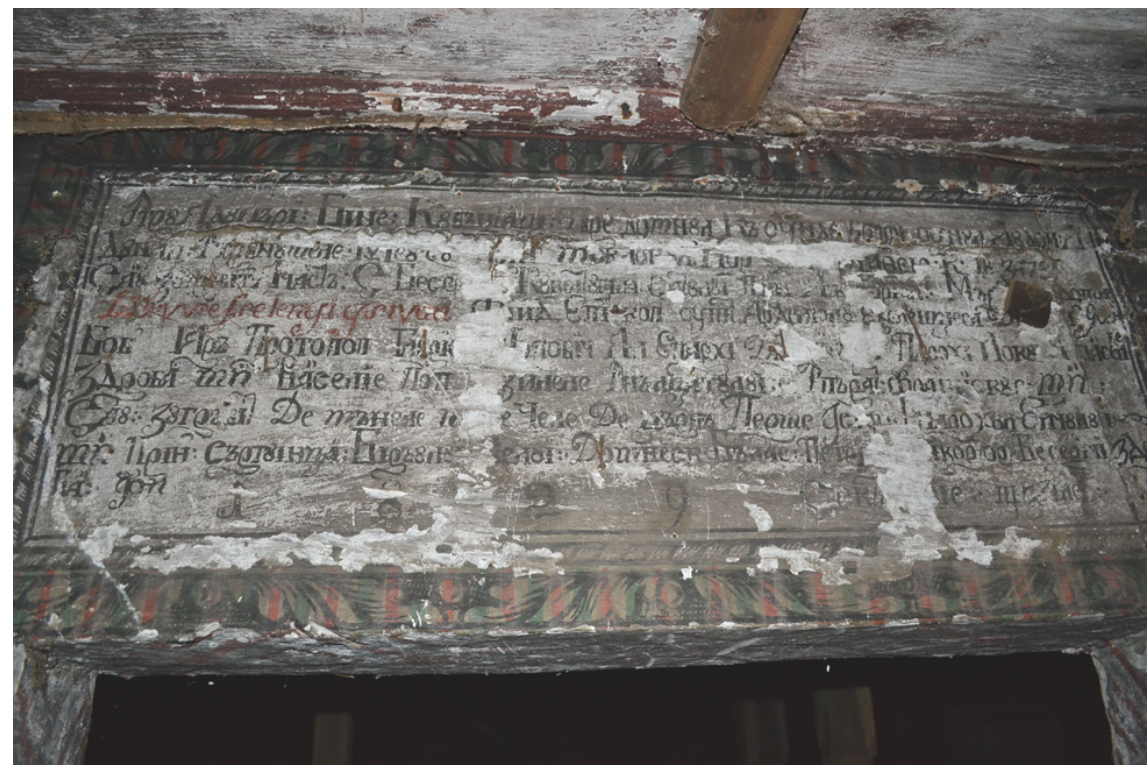

Figure 2. Inscription above the nave entry

The inscription above the nave entry (Fig. 2) specifies the wall painting execution date and name of the painter (1829, losif Perșe), the funds being raised by the villagers. Names of priests, local personalities and emperor are also mentioned.

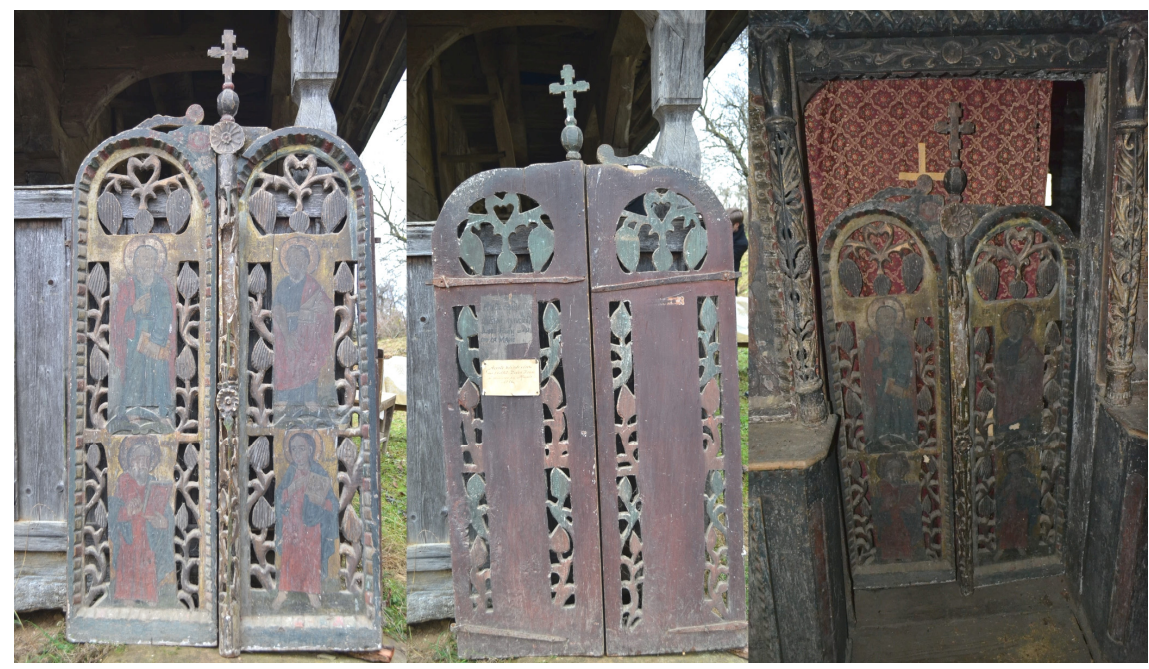

Figure 3. Imperial Gates (front and back) 
The imperial gates, see Fig. 3, are made from a carved piece of wood with frames on the edges and the two icons inside each. The painter made only four icons representing the four evangelists, giving up the icon of the Annunciation probably due to lack of space or material.

According to the inscription on the back side, the imperial gates were made and painted in 1816.

This study aims to investigate the materials used by the painter for conservation and restoration purposes and to compare them with contemporary Transylvanian paintings. The pigment palette richness can also offer an insight to the economic situation of the local community, which provided the financial support for the execution.

\section{RESULTS AND DISCUSSION}

\section{XRF- Spectroscopy}

The non-destructive XRF spectroscopy investigations were performed in situ with a portable spectrometer and the analyzes targeted the primer layer and each color from the painting layer at different points.

The spectra and compositions of painting materials are presented in the Figs. $4-13$.

Following the analysis of the primer layer (Fig. 4), the presence of large amounts of calcium was found. Fourier transform infrared spectroscopy (Fig. 14) confirmed the presence of gypsum (hydrated calcium sulfate).

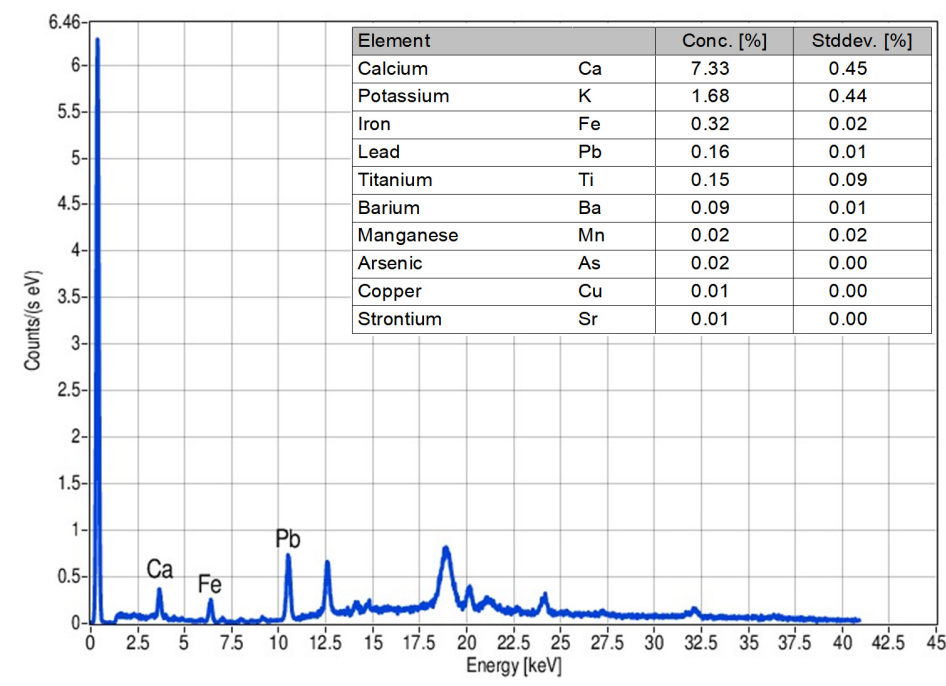

Figure 4. XRF spectrum of ground - Calcium based - Gypsum (confirmed by FTIR spectrum) 


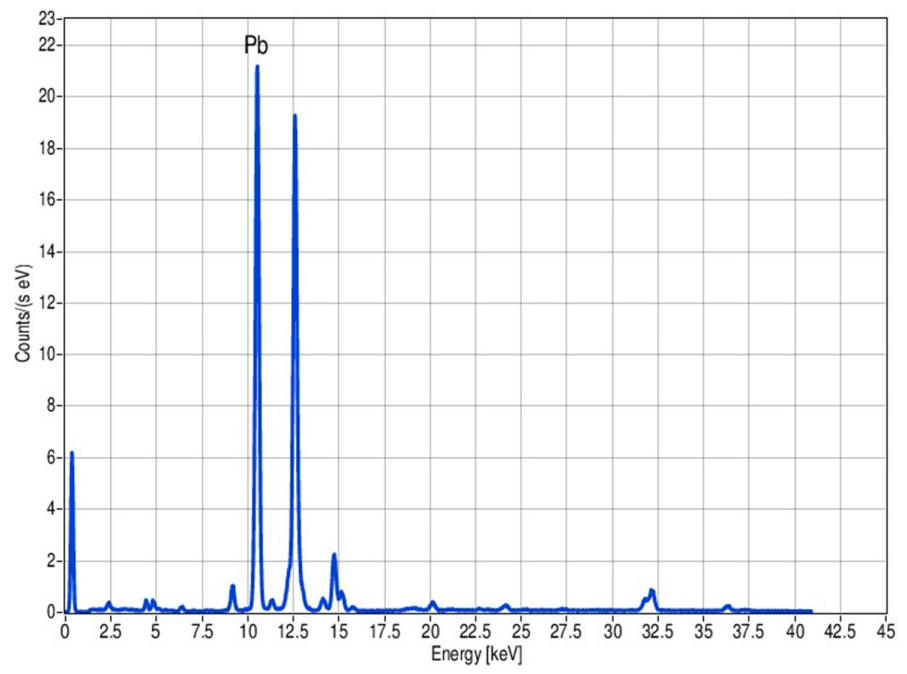

Figure 5. XRF spectrum of white colour - lead white

As can be seen in the XRF spectrum shown in Fig. 5, the painter used lead hydroxycarbonate to render the white colour.

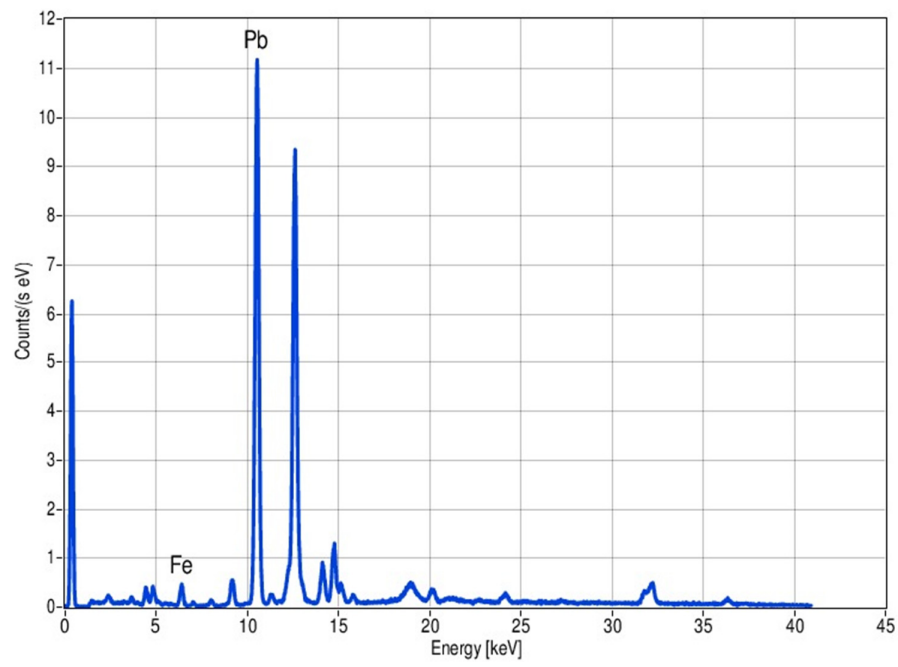

Figure 6. XRF spectrum of blue colour - Prussian blue mixed with lead white (confirmed by FTIR spectrum)

The XRF spectrum for the blue colour shows the presence of iron, indicating that for this colour the author used Prussian blue, which is confirmed 
VICTOR CONSTANTIN MARUTOIU, IOAN BRATU,

OLIVIA FLORENA NEMES, CONSTANTIN MARUTOIU

by the FTIR analysis (Fig.16 and Fig. 17). Lead is also present (from lead white, used to decrease the intensity of blue).

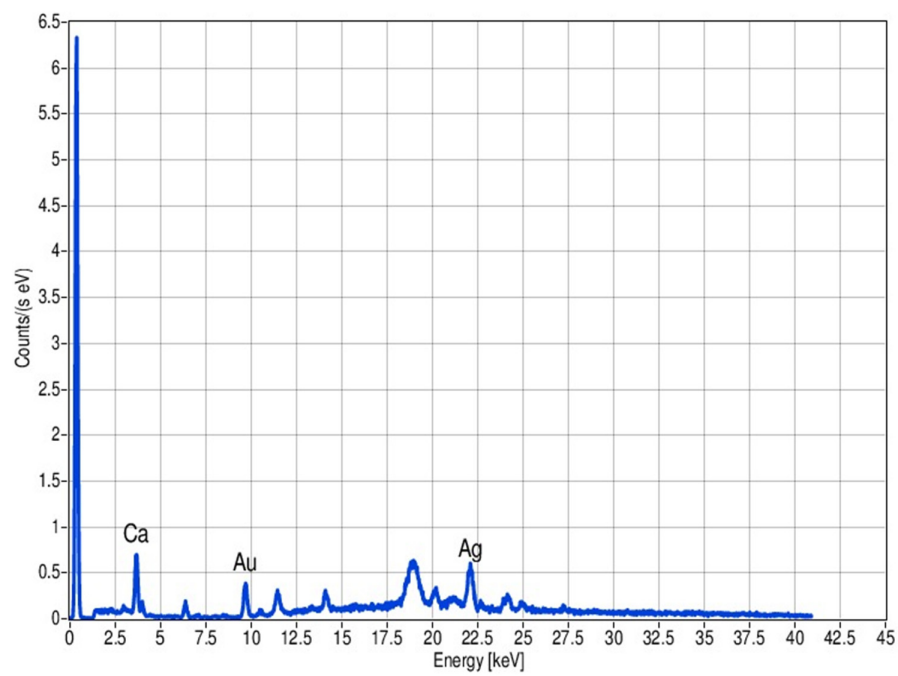

Figure 7. XRF spectrum of aura - gold and silver leaf

Gold and a silver leaf were used for the auras of the saints (Fig.7). The use of gold and silver leaf is of note, a common and cheaper option to obtain the auras was the use of orpiment.

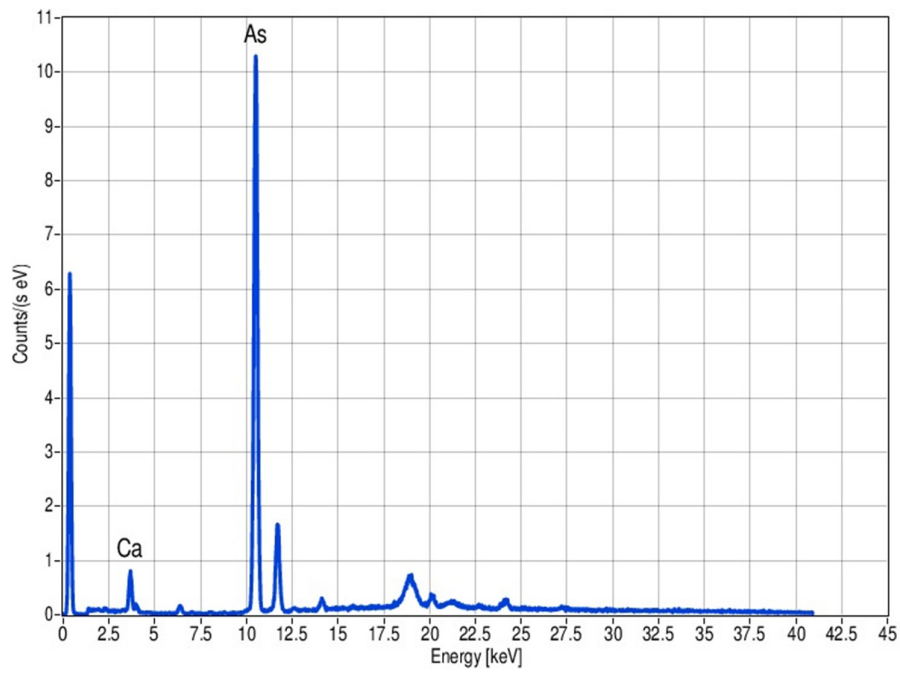

Figure 8. XRF spectrum of yellow pigment - orpiment 
The presence of arsenic in the XRF spectrum of the yellow colour shows the use of orpiment.

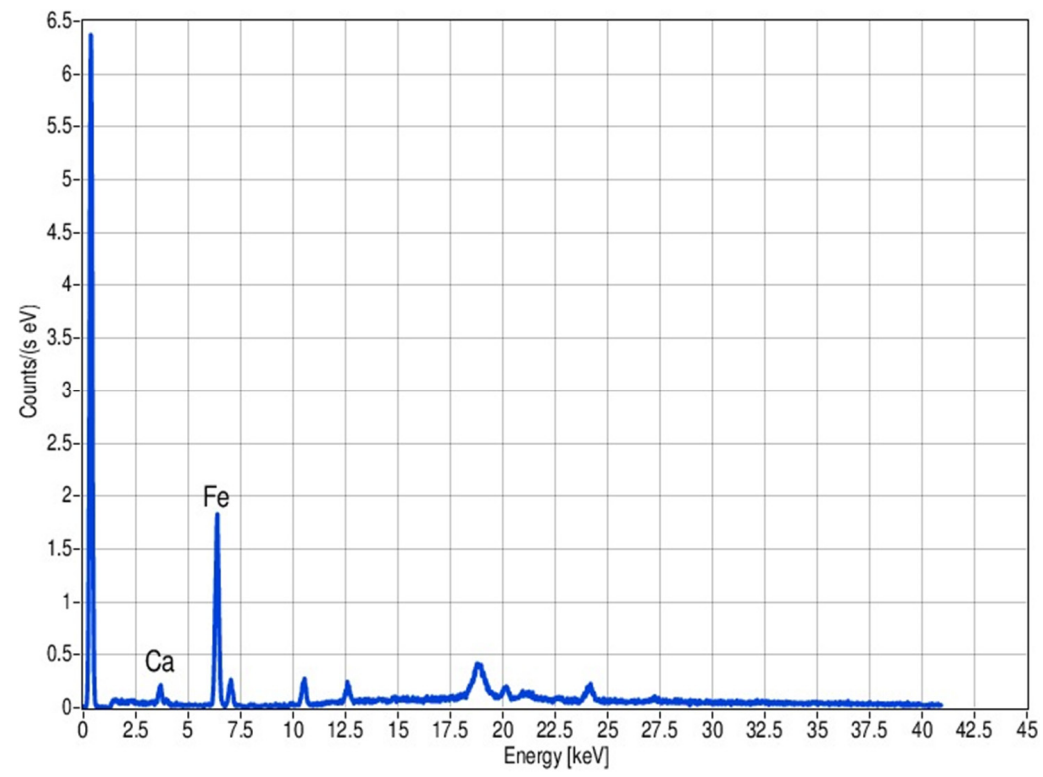

Figure 9. XRF spectrum of red paint - iron red

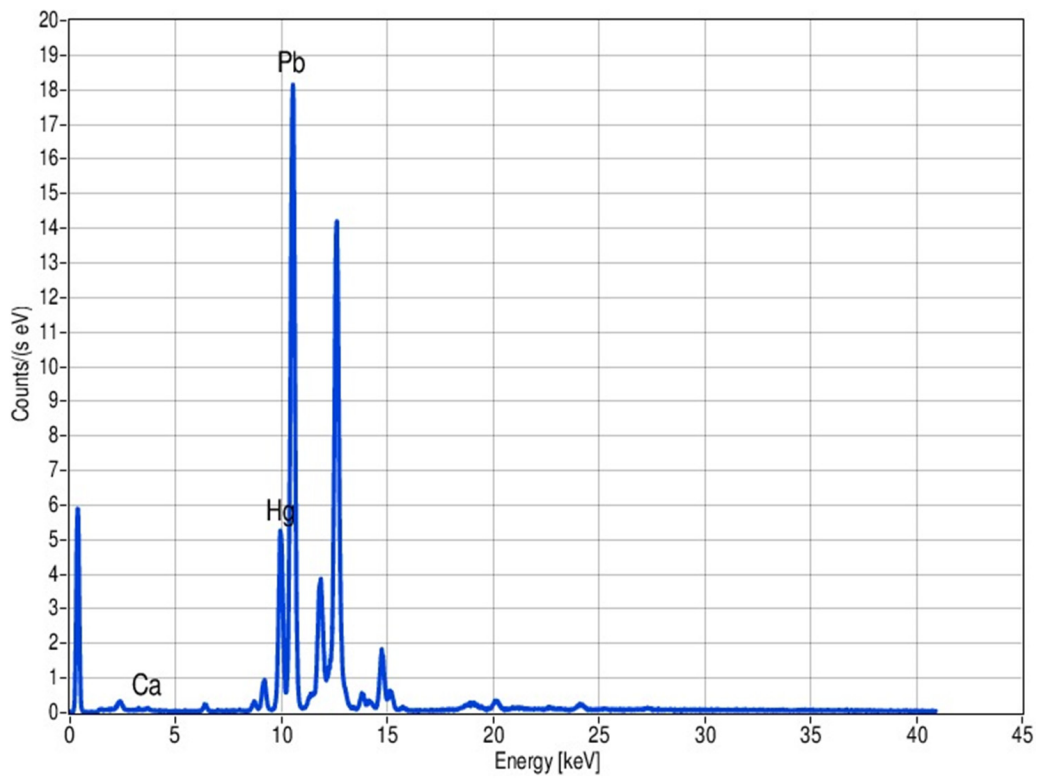

Figure 10. XRF spectrum of red paint - lead read mixed with cinnabar 
VICTOR CONSTANTIN MARUTOIU, IOAN BRATU,

OLIVIA FLORENA NEMES, CONSTANTIN MARUTOIU

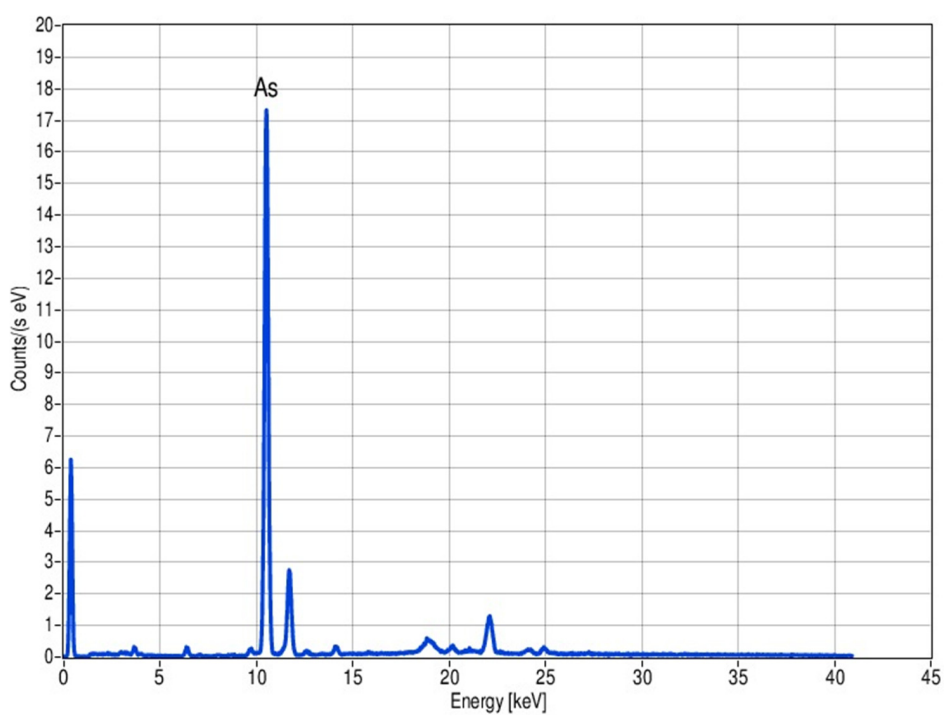

Figure 11. XRF spectrum of red paint (Marc the Evangelist)- realgar

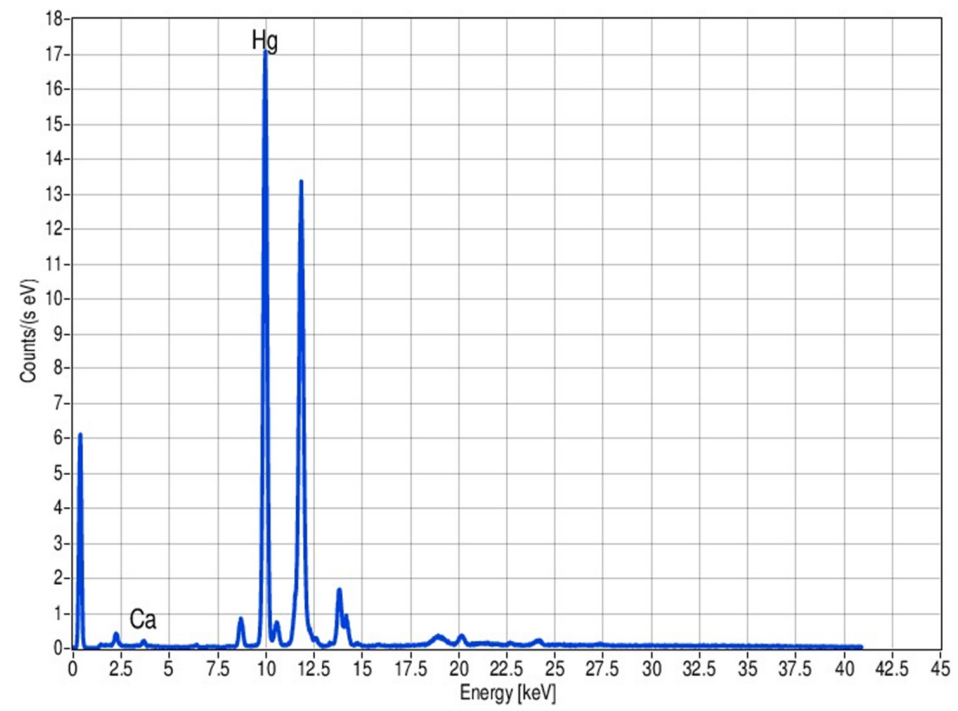

Figure 12. XRF spectrum of red paint from frame - cinnabar

To render the red colour, the author of the icons painted on the imperial gates used several pigments: iron red (Fig.9), lead red mixed with mercury red/cinnabar /(Fig.10) and realgar (Fig.11). The calcium identified in the spectra is from the primer composition. 
The painter used an unusual number of red pigments, four being used individually or in combination to obtain various shades of red (Figs. 912). While the iron red and red led were commonly used in that period, the cinnabar (mercury sulfide) was used more scarcely, sometimes in just a few places (for the most important biblical figures) or smaller quantities (to give a slight red shade to the white carnation of depicted characters). The use of realgar, an arsenic sulfide mineral is of special note, not being previously detected by the current research team in other Transylvanian wooden church paintings and icons [7-12].

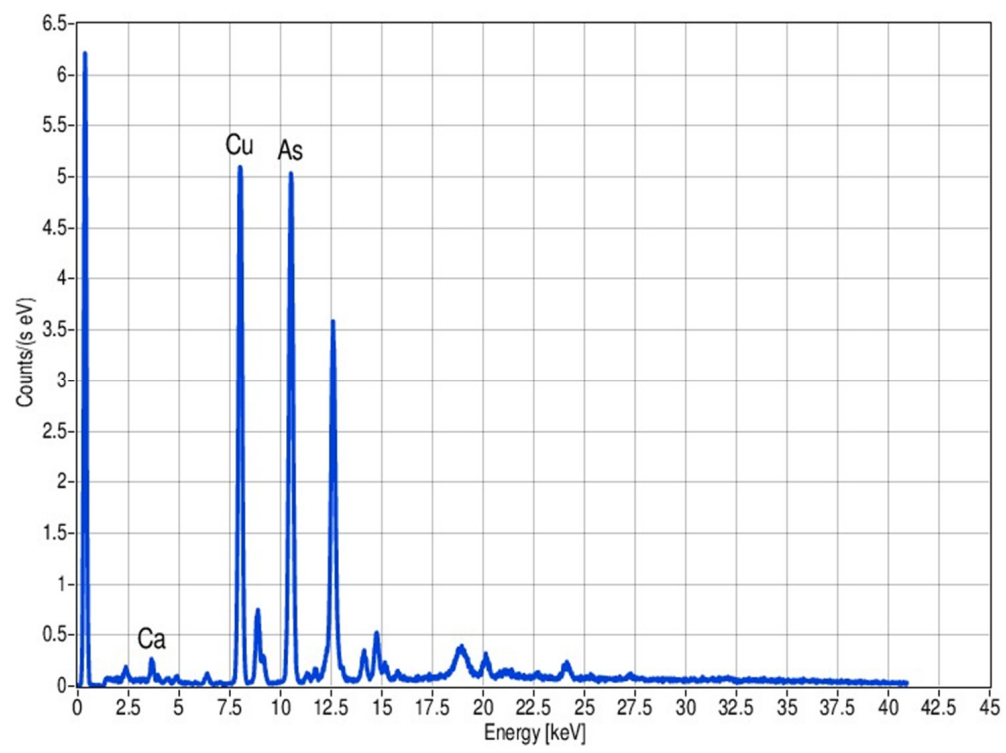

Figure 13. XRF spectrum of green paint - Scheele's green

The pigment used for the green colour was Scheele's green (shown by the presence of arsenic and copper in the Fig. 13 XRF spectrum).

The presence of the Scheele's green is of note, discovered in 1775 (the most commonly used green pigments in other contemporary wooden church paintings and icons being malachite, verdigris or green earth).

\section{FTIR Spectroscopy}

The identification of painting materials and of the wood are presented In the Figs $14-18$. 
VICTOR CONSTANTIN MARUTOIU, IOAN BRATU,

OLIVIA FLORENA NEMES, CONSTANTIN MARUTOIU

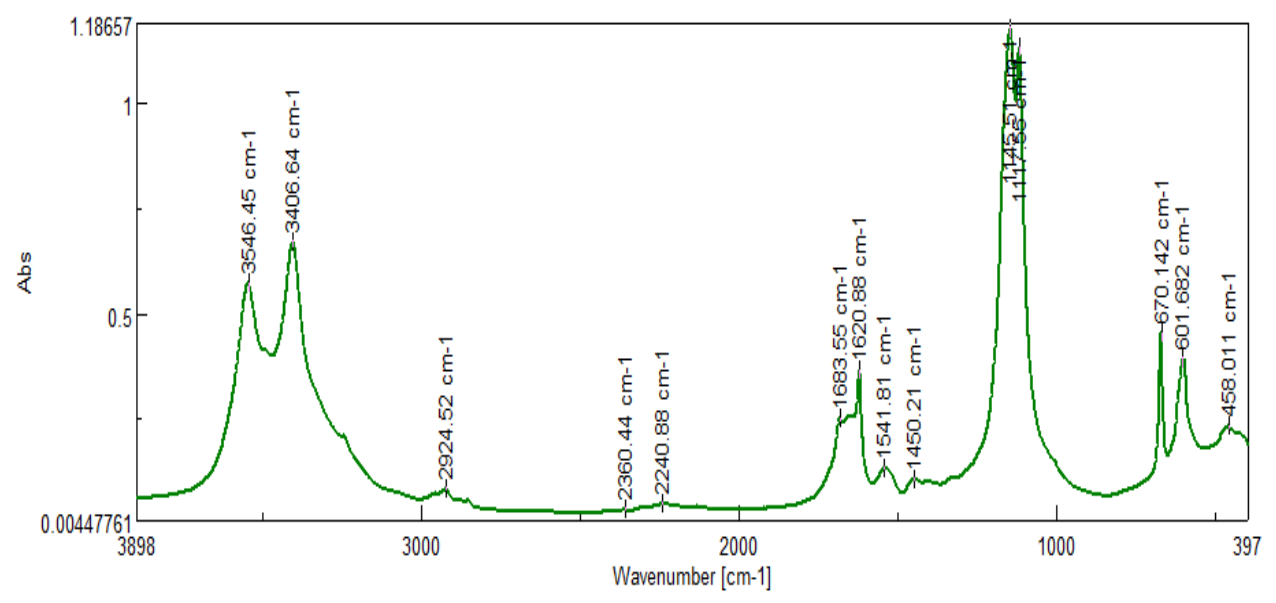

Figure 14. FTIR spectrum of gypsum ground Gypsum: 3546, 2306, 1620, 1145, 1114 and $670 \mathrm{~cm}^{-1}$

Proteins: 2924, 1645, $1541 \mathrm{~cm}^{-1}$

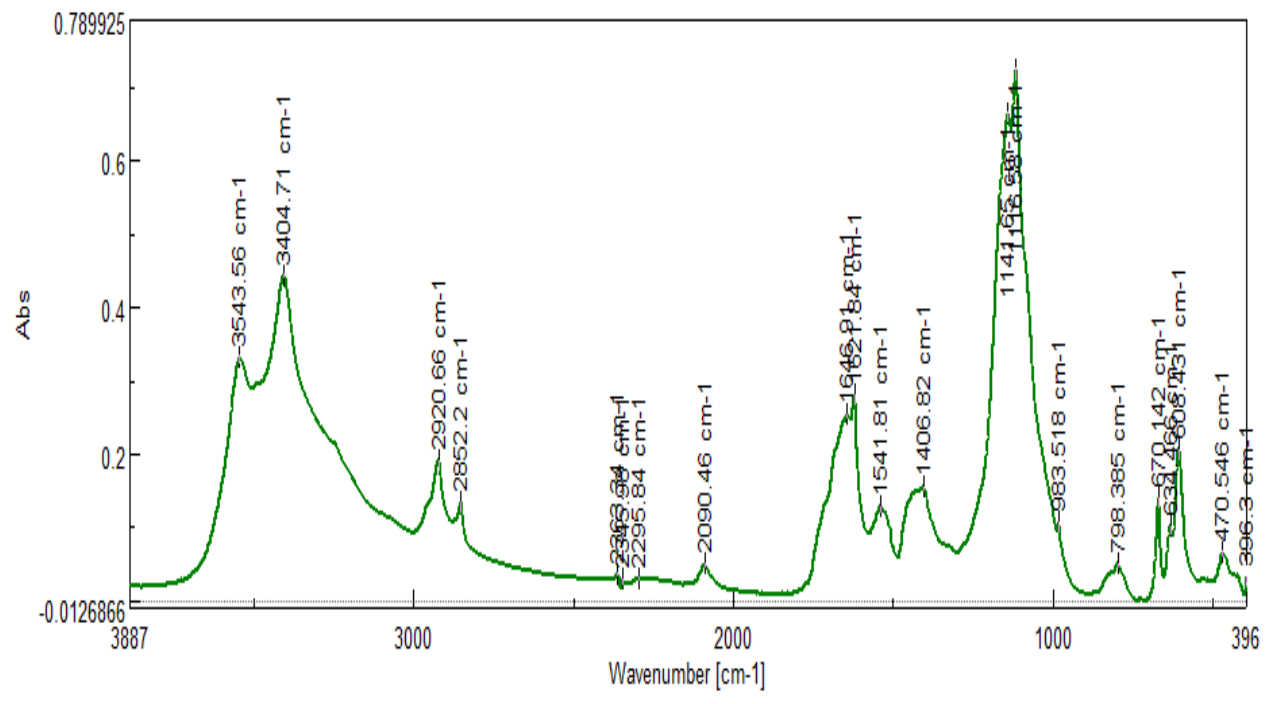

Figure 15. FTIR spectrum of yellow painting material.

Composition: gypsum $\left(3546,2306,1620,1145,1114\right.$ and $\left.670 \mathrm{~cm}^{-1}\right)$,

Proteins (2929, 2852, 1646, 1541, $\left.793 \mathrm{~cm}^{-1}\right)$, orpiment (based only on XRF data) 


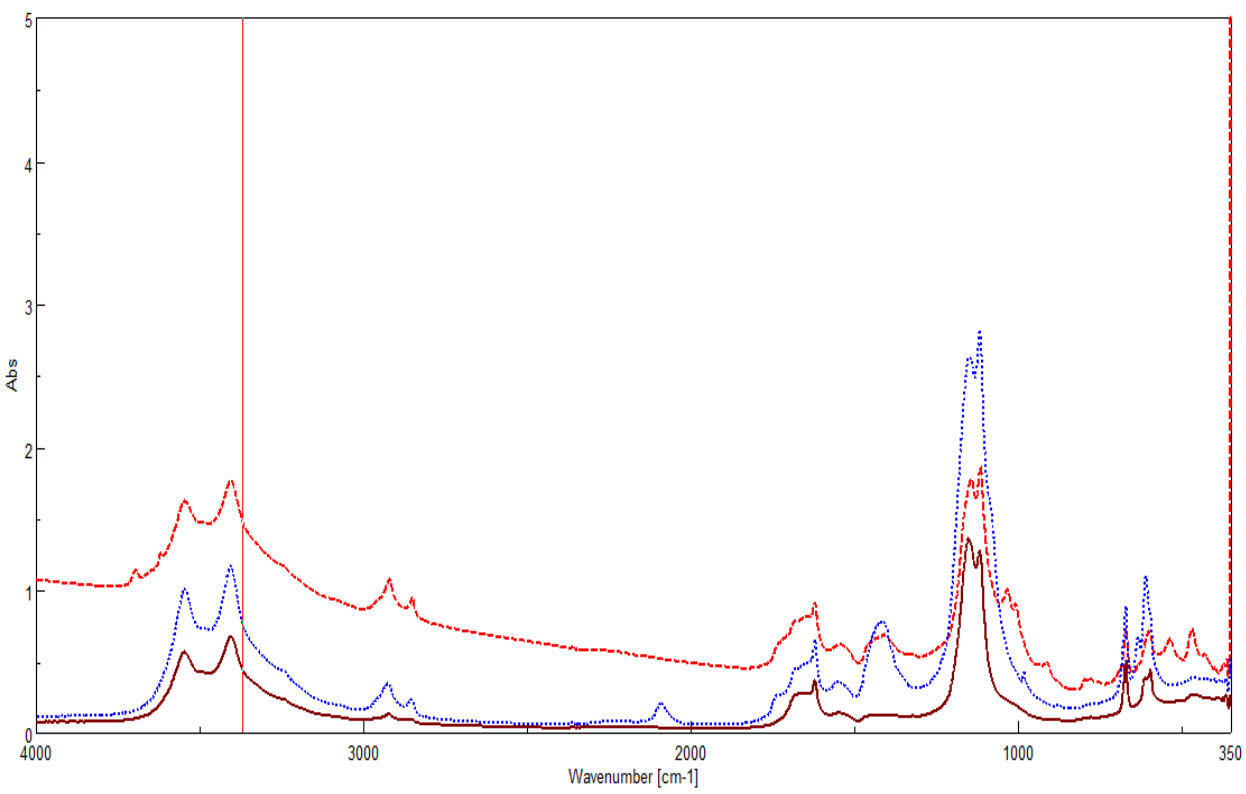

Figure 16. FTIR spectra of the blue painting material- blue line

Prussian blue pigment; red line - red lead on frame $\left(\sim 530\right.$ and $\left.475 \mathrm{~cm}^{-1}\right)$; violet line - red pigment (mercury red, based only on XRF data)

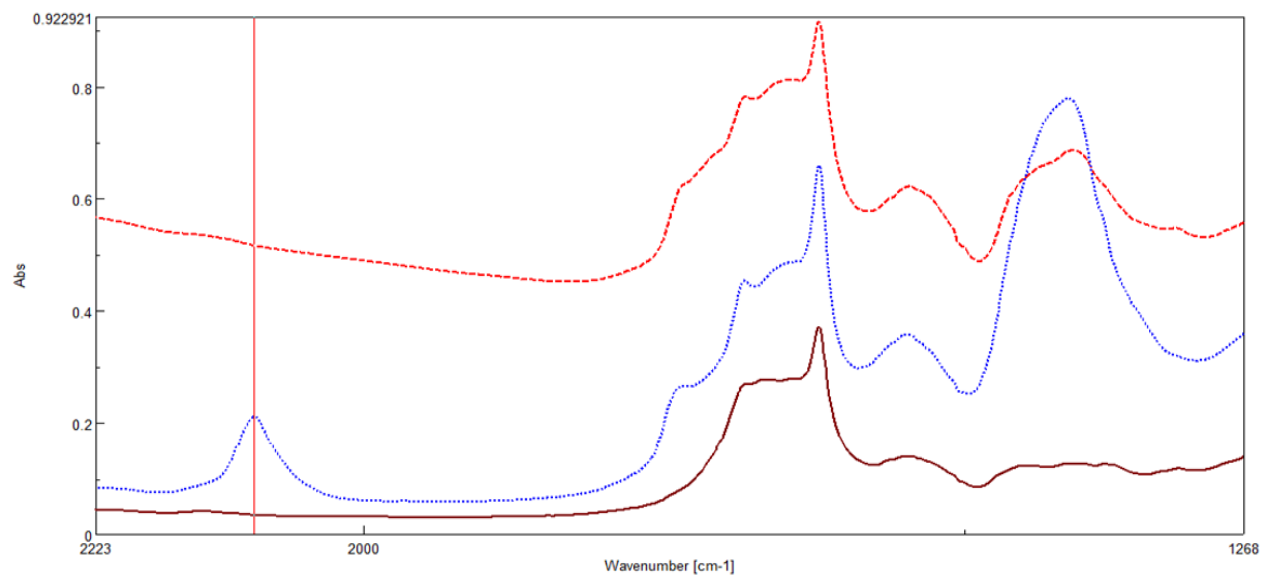

Figure 17. FTIR spectra of the blue painting material detailed - blue line Prussian blue pigment (specific peak at $2091 \mathrm{~cm}^{-1}$ ); red line - red frame; violet line - red pigment 


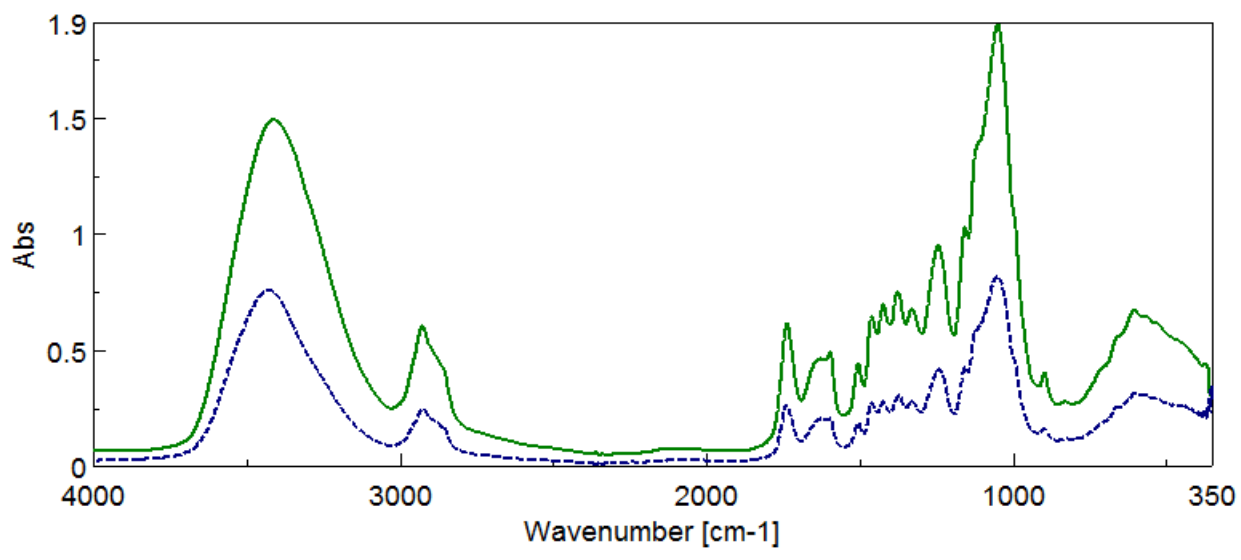

Figure 18. FTIR spectra of wooden samples: green line-Imperial Gate wood; blue dash line - linden standard wood (based on absorptions located at 3400 and $1100-1000 \mathrm{~cm}^{-1}$ )

The spectra comparison from Fig.18 is showing that the wood species used to manufacture the imperial gates is linden wood [13].

\section{CONCLUSIONS}

The imperial gates from the Dragu wooden Church are made from linden wood. The painting materials used by the painter are: gypsum for ground; lead white, Prussian blue, gold and silver leaf, iron red, lead red, cinnabar, realgar, orpiment, Scheele's green for pigments; egg yolk and bone glue as binders.

The rich palette of pigments is unusual compared to other sites, especially shown by the use of four different red pigments. This also suggests a better economic state of the community or possibly support received (the inscription above the nave entry mentioning help from a baron), many other communities from that time didn't afford such a vast palette of materials.

Many of the pigments used have various levels of toxicity (lead from red and white lead pigments, mercury from cinnabar, arsenic from realgar, orpiment and Scheele's green). While most of them were commonly used in the era, their very rich selection in only one site is of note. 


\section{EXPERIMENTAL SECTION}

\section{Non-destructive XRF spectroscopy}

Non-destructive X-ray fluorescence elemental analysis (XRF) was performed with a handheld Bruker spectrometer, S1 TITAN series (EDXRF) configured with a Silicon diode PIN detector (SiPIN), Rh target X-ray tube with a maximum voltage of $50 \mathrm{kV}$.

\section{FTIR absorption spectroscopy}

Fourier-transform Infrared (FTIR) measurements were performed in the 4000 to $400 \mathrm{~cm}^{-1}$ spectral range with a Jasco 6100 spectrometer with a resolution of $4 \mathrm{~cm}^{-1}$ (256 scans) by employing $1(<1) \mathrm{mg}$ of sample and about $200 \mathrm{mg}$ of pure spectral $\mathrm{KBr}$ (KBr pellet technique was applied). The FTIR spectra were processed with the Spectral Analysis software.

\section{DISCLOSURE} authors.

Victor Constantin Măruțoiu and Olivia Florena Nemeș are co-first

\section{ACKNOWLEDGMENTS}

The paper was realised within the research project: „Elaborating Complex Methodologies Regarding the Attribution and Authentication of Certain Paintings from the Medieval and Early Modern Periods Belonging to the National Cultural Heritage", project number 53-PCCDI/2018, code: PN-III-P1-1.2-PCCDI-2017- 0812.

\section{REFERENCES}

1. A. Bârcă, Biserici de lemn din Sălaj, Ed. Noi Media Print, București, 2011.

2. I. Godea, Biserici de lemn din România (nord-vestul Transilvaniei), Ed. Meridiane, Bucuresti, 1996.

3. C. Brăcắcescu, Lăcașuri din lemn: biserici de sat din Sălaj, Ed. Igloo Media, București, 2015.

4. I. Cristache-Panait, Buletinul Monumentelor Istorice, 1971, 1, 31-40. 
5. I. Godea, I. Cristache-Panait, Monumente istorice bisericești din Eparhia Ortodoxă Română a Oradiei. Biserici de lemn, Ed. Episcopiei Ortodoxe Române a Oradiei, Oradea, 1978.

6. C. Zebacinschi, I. Ciocian, Acta Musei Porolissensis,1984, VIII, 775-792.

7. O.F. Nemeș, I. Bratu, C. Măruțoiu, I. Kacso, M. Miclăus, D. Mihali, D. Nica Badea, Rev.Chim. (Bucharest), 2018, 69, No. 1, 76-79.

8. I. Bratu, O.F. Nemeş, V.C. Mãruţoiu, I. Kácso, D.Gh. Vlasin, ,Anal. Lett., 2019, $52,45-50$.

9. I. Bratu, C. Măruțoiu, D. Nemeș, D. Toader, O.F. Nemeș, R.C. Suciu, Anal. Lett, 2020, 53, 204-211.

10. D. Nemeș, C. Măruțoiu, I. Bratu, C. Neamțu, I. Kacso, O.F. Nemeș, I. Udrea, Characterization of the Paint Used by Dumitru Ispas in the Wooden Straja Church, Cluj County, Romania, Anal. Lett, 2020, 54:1-2, 255-264.

11. C. Neamțu, V.C. Măruțoiu, I. Bratu, O.F. Măruțoiu, C. Măruțoiu, I. Chirilă, M. Dragomir, D. Popescu, Sustainability 2018, 10, 1503.

12. O.F. Măruțoiu, I. Bratu, C. Măruțoiu, D.L. Postolache, M. Dragomir, C. Tanaselia, S. Garabagiu, X -Ray Spectrometry, 2018, 47, 176-185.

13. M. Poletto, V. Pistor, A.J. Zattera, Structural characteristics and thermal properties of native cellulose. In Cellulose - Fundamental Aspects, Theo G.M. van de Ven Eds.; Intechopen, London, UK, 2013. 